\title{
Genetic diversity of Salminus brasiliensis wild populations in downstream and upstream Cachoeira Branca, Verde River MS Brazil: a preliminary view
}

\section{Diversidade genética de populações naturais de Salminus brasiliensis à jusante e montante da Cachoeira Branca, rio Verde - MS (Brasil): uma visão inicial}

\author{
Ricardo Pereira Ribeiro ${ }^{1}$; Nelson Mauricio Lopera-Barrero ${ }^{2 *}$; \\ Jayme Aparecido Povh ${ }^{3}$; Maria del Pilar Rodriguez-Rodriguez; \\ Darci Carlos Fornari ${ }^{5}$; Gilmar Baumgartner ${ }^{6}$; Dirceu Baumgartner ${ }^{6}$; \\ Felipe Pinheiro de Souza ${ }^{7}$; Pedro Luiz de Castro $^{8}$; Angela Rocio Poveda-Parra ${ }^{9}$
}

\begin{abstract}
Although hydroelectric power plants generate most electricity in Brazil, the dams provide environmental barriers which also include the interruption of fish migration. Current study, conducted prior to the construction of São Domingos HPP on the shaft of the Cachoeira Branca (waterfall) on the Verde river, state of Mato Grosso do Sul, Brazil, evaluated the genetic diversity of two natural populations of dourado (Salminus brasiliensis) located downstream (Population A - PopA) and upstream (Population B - PopB) the waterfall. Eight primers were employed to analyze 56 specimens (PopA: 26; PopB: 30) and observed in 102 fragments, of which 86 were polymorphic (84.3\%). Low frequency fragments (PopA: 2; PopB: 1), three limiting fragments (PopA) and three exclusive fragments (PopB) were identified. The intra-population genetic variability calculated the Shannon index, whilst the percentage of polymorphic fragments showed high rate variability within each population (PopA: 0.300 and $60.80 \%$ and PopB: 0.411 and $79.40 \%$, respectively). The distance and genetic identity revealed high genetic differentiation (0.076 and 0.927, respectively). Results reveal that populations have high intra-population genetic variability and genetic differentiation between them, with low gene flow.
\end{abstract}

Key words: Conservation genetic, dourado, hydroelectric power plants, genetic variability

\footnotetext{
${ }^{1}$ Prof. Dr., Dept ${ }^{\circ}$ de Zootecnia, Programa de Pós-Graduação em Zootecnia, Universidade Estadual de Maringá, UEM, Maringá, PR, Brasil. E-mail: rpribeiro@uem.br

${ }^{2}$ Prof. Dr., Dept ${ }^{\circ}$ de Zootecnia, Programa de Pós-Graduação em Ciência Animal, Universidade Estadual de Londrina, UEL, Londrina, PR, Brasil. E-mail: nmlopera@uel.br

3 Prof. Dr., Universidade Federal de Mato Grosso do Sul, UFMS, Campo Grande, MS, Brasil. E-mail: jayme.peixegen@gmail.com

${ }^{4}$ Pesquisadora, Universidade Federal dos Vales de Jequitinhonha e Mucuri, UFVJM, Diamantina, MG, Brasil. E-mail: rodrigpilar@ gmail.com

5 Diretor Executivo, Genetic Fish Rise, Primavera do Norte, Sorriso, MT, Brasil. E-mail: darci.peixegen@gmail.com

${ }^{6}$ Profs. Drs., Universidade Estadual do Oeste do Paraná, UNIOESTE, Toledo, PR, Brasil. E-mail: gilmar_baum@yahoo.com.br; baum.d@hotmail.com

${ }^{7}$ Discente do Curso de Mestrado do Programa de Pós-Graduação em Ciência Animal, UEL, Londrina, PR, Brasil. E-mail: felipeps1991@gmail.com

${ }^{8}$ Discente do Curso de Doutorado do Programa de Pós-Graduação em Zootecnia, UEM, Maringá, PR, Brasil. E-mail: pedrocastro. zoo@hotmail.com

${ }^{9}$ Pós-Doutoranda em Ciência Animal, Dept ${ }^{0}$ de Zootecnia, UEL, Londrina, PR, Brasil. E-mail: angelapovedaparra@hotmail.com

* Author for correspondence
} 


\section{Resumo}

As usinas hidrelétricas são responsáveis por gerar a maioria da energia elétrica utilizada no Brasil, entretanto, suas construções podem gerar entraves ambientais, entre eles a interrupção da migração de peixes. O presente estudo foi realizado no período anterior a construção da Usina Hidroelétrica (UHE) São Domingos sobre o eixo da cachoeira Branca, no rio Verde - Mato Grosso do Sul (Brazil), e teve como objetivo avaliar a diversidade genética de duas populações naturais de dourado (Salminus brasiliensis) localizadas à jusante (População A - PopA) e montante (População B - PopB) da cachoeira. Foram utilizados oito iniciadores para analisar 56 indivíduos (PopA: 26; PopB: 30). Observaram-se um total de 102 fragmentos, dos quais 86 foram polimórficos $(84,3 \%)$. Foram identificados fragmentos de baixa frequência (PopA: 2; PopB: 1), três fragmentos limitantes (PopA) e três fragmentos exclusivos (PopB). A variabilidade genética intra-populacional calculada com o índice de Shannon e pela porcentagem de fragmentos polimórficos mostrou altos valores de variabilidade dentro de cada população (PopA: 0,300 e 60,80\% e PopB: 0,411 e 79,40\%, respectivamente). A distância e identidade genética mostraram uma alta diferenciação genética $(0,076$ e 0,927 , respectivamente). Conclui-se que as populações apresentaram alta variabilidade genética intra-populacional e diferenciação genética entre si, com baixo fluxo gênico.

Palavras-chave: Conservação genética, dourado, usina hidrelétrica, variabilidade genética

\section{Introduction}

Although most electric power in Brazil, specifically $70.81 \%$ of total energy capacity, comes from hydroelectric plants (BRASIL, 2015), dam construction triggers various environmental factors (LIMA, 2015) which greatly affect issues on local fauna, varying in quality and intensity. Fish reproduction strategies, migration patterns, trophic specialization and pre-adaptation degrees to lake environments may be highlighted (AGOSTINHO et al., 2007).

In spite of the fact that dam construction is a source of low-cost and sustainable energy (BRASIL, 2015), it is one of the main causes in the decrease of fish population worldwide since it forms a physical barrier for fish migration and, consequently, fish reproduction, coupled to the fact that it jeopardizes species variability through the use of physical space, changes in food provision and water quality. In fact, dams hinder and delay fish movement towards the upper regions of the hydrographic basin and may even cause gonadal regression and impair reproduction in the current cycle (ANDRADE, 2009).

The dourado (Salminus brasiliensis) (Cuvier, 1816 ) is a migratory and carnivorous fish species, highly appreciated as a fishing sport and for its meat (FLORA et al., 2010; FRACALOSSI et al., 2002). According to Lima et al. (2013), S. brasiliensis is a native fish species characterized by long-distance migration for reproduction. Its greatest activities occur during the hot and rainy period between October and January.

Transposition ladder devices permit the passage of fish between the dam regions (upstream and downstream) (AGOSTINHO et al, 2007), even though only species ascending within these systems has been observed. There are no studies on the importance and effectiveness of these ladders for the preservation of fish populations in hydrographic basins (SIROL; BRITTO, 2006; AGOSTINHO et al., 2007). Moreover, little is known on HPP mechanisms with regard to fish movements and spatial distribution near the dams (SUZUKI, 2014). Further studies on the technical, biological and size aspects of these artificial pathways for migrating fish are needed (ARRAIS et al., 2013) and the way they affect genetic and population aspects.

Since the loss of genetic variability decreases the adaptability and survival of the offspring, genetic diversity in natural stocks should be maintained (POVH et al., 2008a; SAURA et al., 2006). Therefore, the maintenance of genetic diversity 
in natural and strategic stocks that monitor such diversity is mandatory to mitigate the decline in variability and genic flux among divided populations (MARTELETO, 2015).

Current research evaluates the genetic variability of S. brasiliensis populations prior to the construction of the HPP to have an idea of the species's genetic variability.

\section{Materials and Methods}

The HPP São Domingos was built in the Verde river, between the municipalities of Água Clara and Ribas do Rio Pardo in the northeastern region of the state of Mato Grosso do Sul, Brazil. The plant's reservoir merely maintains the required level gap for the generation of electricity. The reservoir started filling on October 5, 2012 and was concluded on January 9, 2013, with 345 m, coupled to the flooding of the Verde, São Domingos and Araras rivers. Electricity generators 1 and 2 started functioning on June 2013 and July 2013, respectively (ELETROBRAS-ELETROSUL, 2014). The plant was built on the Cachoeira Branca axis which, in its turn, was characterized by a set of two waterfalls, with strong rapids for approximately $1200 \mathrm{~m}$ in length, 75 $\mathrm{m}$ wide and a $9 \mathrm{~m}$ level gap between waterfalls. Prior to the construction of the electric plant, it seemed to have been a physical barrier for the migration of fish.

Fins of $S$. brasiliensis were collected between November 2010 and March 2011 at two sites, downstream (Population A) and upstream (Population B) of Cachoeira Branca to analyze the genetic variability. Fifty-six caudal fins (300 - 400 $\mathrm{mg}$ ) were collected from Population A (26 samples) and from Population B (30 samples).

DNA was extracted according to methodology by Lopera-Barrero et al. (2008a), or rather, 550 $\mu \mathrm{L}$ lysis buffer $\left(50 \mathrm{mmol} \mathrm{L}^{-1}\right.$ Tris- $\mathrm{HCl}, 50 \mathrm{mmol}$ $\mathrm{L}^{-1}$ EDTA, $100 \mathrm{mmol} \mathrm{L}^{-1} \mathrm{NaCl}$ and $1 \% \mathrm{SDS}$ ) and $7 \mu \mathrm{L}$ proteinase $\mathrm{K}\left(200 \mathrm{mg} \mu \mathrm{L}^{-1}\right)$ were added to microtubes with the fins. The material was incubated in a warm bath at $50^{\circ} \mathrm{C}$ for 12 hours. DNA was precipitated with $600 \mu \mathrm{L}$ of $\mathrm{NaCl}$ solution (5 $\mathrm{mol} \mathrm{L}^{-1}$ ) and centrifuged for $10 \mathrm{~min}$ at $14.645 \mathrm{~g}$. The supernatant with DNA was transferred to $800 \mu \mathrm{L}$ microtube, precipitated with $700 \mu \mathrm{L}$ absolute ethyl alcohol and incubated for 1 hour at $-20^{\circ} \mathrm{C}$. DNA was then centrifuged, washed in $700 \mu \mathrm{L}$ ethyl alcohol $70 \%$, suspended in $85 \mu \mathrm{L}$ TE buffer $\left(10 \mathrm{mmol} \mathrm{L}^{-1}\right.$ Tris $\mathrm{pH} 8$ and $1 \mathrm{mmol} \mathrm{L}^{-1}$ EDTA) and treated with 7 $\mu \mathrm{L}$ RNAse $\left(30 \mathrm{mg} \mathrm{mL}^{-1}\right)$ in a warm bath at $37^{\circ} \mathrm{C}$ for 1 hour. After the above procedures, the material was stored in a freezer at $-20^{\circ} \mathrm{C}$.

DNA was quantified in a spectrophotometer (Shimadzu Corporation, Kyoto, Japan) with $260 \mathrm{~nm}$ absorbance. Samples were diluted for a concentration of $10 \mathrm{ng} \mu \mathrm{L}^{-1}$. Agar gel electrophoresis $1 \%$ was performed to guarantee the quality of extracted DNA, by buffer TBE $1 X\left(500 \mathrm{mmol} \mathrm{L}^{-1}\right.$ Tris-HCl, $60 \mathrm{mmol} \mathrm{L}^{-1}$ boric acid and $83 \mathrm{mmol} \mathrm{L}^{-1}$ EDTA), for 1 hour, at 70 volts.

Amplification conditions were based on procedures by Williams et al. (1990), with modifications. DNA was amplified in a $15 \mu \mathrm{L}$ reaction volume in which $1 \mathrm{X}$ Tris- $\mathrm{KCl}, 2 \mathrm{mmol}$ $\mathrm{L}^{-1}$ de $\mathrm{MgCl} 2,0.46 \mu \mathrm{mol} \mathrm{L}-1$ starter, $0.2 \mathrm{mmol} \mathrm{L}^{-1}$ of each dNTP, one Platinum Taq DNA Polymerase unit (Invitrogen, Carlsbad, USA), and 10 ng target DNA, were used as buffer.

DNA was denatured at $92^{\circ} \mathrm{C}$ for 4 min; 40 cycles were performed, each with $40 \mathrm{~s}$ denaturation at $92^{\circ} \mathrm{C} ; 1: 30 \mathrm{~min}$ annealing of starter at $40^{\circ} \mathrm{C} ; 2 \mathrm{~min}$ for extension at $72^{\circ} \mathrm{C}$; followed by a final extension at $72^{\circ} \mathrm{C}$ for $5 \mathrm{~min}$. Reaction were amplified in an Eppendorf MasterCycler Gradient thermal cycler. Eight different 10-base starters were chosen from Kits OPA, OPW and OPX (Operon Technologies Ltd., Valencia, USA) with the best definition and reproducibility (Table 1$)$.

Amplification products were separated by agar gel $1.5 \%$ and $15 \mu \mathrm{L}$ of the amplified product and $2 \mu \mathrm{L}$ of the sample buffer $(40 \%$ sucrose and $0.25 \%$ bromophenol blue) were used in horizontal 
electrophoresis. Electrophoresis was conducted in TBE $0.5 \mathrm{X}$ buffer $\left(45 \mathrm{mmol} \mathrm{L} \mathrm{L}^{-1}\right.$ Tris-Borate and 1 mmol L-1 EDTA) during 4 hours, at 70 volts. Quantification and amplification gels were perceived under UV radiation after exposure with ethidium bromide $\left(0.5 \mu \mathrm{g} \mathrm{mL}^{-1}\right)$ for $1 \mathrm{~h}$. The image was photographed by a Loccus Trans-illuminator L PIX (USA).

Table 1. Sequences of starter nucleotides, percentage of pyrimidine bases $G+C$, number of fragments and size of amplified fragments for populations of $S$. brasiliensis.

\begin{tabular}{llccc}
\hline \multicolumn{1}{c}{ Starters } & $\begin{array}{c}\text { Nucleotide sequence } \\
\left(\mathbf{5}^{\prime} \boldsymbol{\rightarrow} \mathbf{3}^{\prime}\right)\end{array}$ & $\mathbf{\%}(\mathbf{G}+\mathbf{C})$ & $\begin{array}{c}\text { Number of } \\
\text { fragments }\end{array}$ & Size of fragments (bp) \\
\hline OPA02 & 5'-TGCCGAGCTG-3' & 70 & 18 & $240-1900$ \\
OPA16 & 5'-AGCCAGCGAA-3' & 60 & 15 & $320-2300$ \\
OPW04 & 5'-CAGAAGCGGA-3' & 60 & 07 & $500-1400$ \\
OPW06 & 5'-AGGCCCGATG-3' & 70 & 16 & $500-2300$ \\
OPW19 & 5'-CAAAGCGCTC-3' & 60 & 11 & $320-2400$ \\
OPX01 & 5'-CTGGGCACGA-3' & 70 & 09 & $800-2072$ \\
OPX09 & 5'-GGTCTGGTTG-3' & 60 & 14 & $300-2000$ \\
OPX13 & 5'-ACGGGAGCAA-3' & 60 & 12 & $350-2072$ \\
\hline Total & - & - & $\mathbf{1 0 2}$ & $\mathbf{2 4 0 - 2 4 0 0}$ \\
\hline
\end{tabular}

Size of fragments by amplifications was estimated by comparing to standard ladder 100 bp (Invitrogen, Carlsbad, USA). The presence or absence of identical molecular sizes was employed to build a similarity matrix based on Jaccard's similarity coefficient, coding 1 as presence of fragment and 0 as absence.

Shannon's genetic diversity index and percentage of polymorphic fragments ( $95 \%$ criterion) were obtained by PopGene 1.31 (YEH et al., 1999), whilst TFPGA 1.3 (MILLER, 1997) determined genetic distance and identity (RAYMOND; ROUSSET, 1995). Arlequin 3.0 (EXCOFFIER et al., 2005) determined the genetic differentiation by Fst (ancestry coefficient) estimates (WEIR; COCKERHAM, 1984) and for the analysis of molecular variance (EXCOFFIER et al., 1992). The significance of tests was verified by the randomized permutation method, with 1,000 and 10,000 permutations. The program was also employed to determine the number of migrants per generation $(\mathrm{Nm})$. The statistical significance of Fst was obtained by $\chi^{2}$ test $\left[c^{2}=2 n\right.$ Fst $(\mathrm{k}-1) ; \mathrm{GL}=(\mathrm{k}-1)(\mathrm{s}-1)]$, following Workman and Niswander (1970), in which: $\mathrm{n}$ is the number of specimens in the two groups; $\mathrm{k}$ is the number of alleles; $s$ is the number of groups. The greatness of genetic difference between stocks was calculated according to Wright (1978), or rather, low (Fst $=0$ $0.05)$; moderate $(\mathrm{Fst}=0.05-0.15)$; high $(\mathrm{Fst}=0.15$ $-0.25)$ and very high (Fst $>0.25)$.

\section{Results and Discussion}

One hundred and two fragments were detected of which $86(84.3 \%)$ were polymorphic. The number of fragments ranged between 7 and 18, sized between 240 and $2400 \mathrm{bp}$ (Table 1). Some studies on $S$. brasiliensis provided number of fragments and polymorphism very similar to current assay. Gomes et al. (2011) studied restocking programs and detected 96 fragments analyzed for 8 starters and between 7 and 17 fragments per starter, of which $78(81.25 \%)$ were polymorphic. Gomes et al. (2013) obtained 105 amplified fragments (79 or $75.2 \%$ were polymorphic) from the same species captured in the transposition ladder in the Canoas I 
hydroelectric plant.

Differences $(p<0.05)$ at the frequency of 11 out of 102 fragments were reported among populations. Low frequency fragments (less than 0.100) were reported in A (2) and B (1). Three limiting fragments (frequency of 1,000) were registered in population $\mathrm{A}$ and three exclusive fragments (not present in other populations) in population B (Table 2).
According to Jacometo et al. (2010), low frequency fragments may be due either to the bottleneck effect or to the founder effect. Although results provided low frequency fragments in both populations, a high genetic variability exists within each stock, tending towards population differentiation. The above shows that the reproduction of specimens in the two places may have contributed to maintain genetic variability.

Table 2. Characterization, base pairs (bp) and frequency of fragments with significant rates by exact test $(\mathrm{p}<0.05)$ for populations A and B of S. brasiliensis.

\begin{tabular}{|c|c|c|c|}
\hline \multicolumn{4}{|c|}{ OPA02 } \\
\hline bp & $\mathbf{A}$ & B & $\mathbf{P}$ \\
\hline 1250 & 0.639 & 0.247 & 0.001 \\
\hline 1150 & 0.067 & 0.394 & 0.000 \\
\hline \multicolumn{4}{|c|}{ OPA16 } \\
\hline pb & $\mathbf{A}$ & B & $\mathbf{P}$ \\
\hline 1700 & --- & $0.742^{*}$ & 0.000 \\
\hline 1500 & 1.000 & 0.452 & 0.000 \\
\hline 1300 & 1.000 & 0.017 & 0.000 \\
\hline 1050 & 0.021 & 0.817 & 0.000 \\
\hline 950 & --- & $0.517^{*}$ & 0.000 \\
\hline \multicolumn{4}{|c|}{ OPW06 } \\
\hline $\mathrm{pb}$ & $\mathrm{A}$ & $\mathrm{B}$ & $\mathrm{P}$ \\
\hline 1850 & 1.000 & 0.475 & 0.000 \\
\hline \multicolumn{4}{|c|}{ OPX09 } \\
\hline pb & $\mathbf{A}$ & B & $\mathbf{P}$ \\
\hline 2000 & --- & $0.413^{*}$ & 0.000 \\
\hline 1150 & 0.110 & 0.305 & 0.000 \\
\hline 490 & 0.354 & 0.678 & 0.000 \\
\hline
\end{tabular}

* exclusive fragments.

Genetic variability in the stocks, calculated by Shannon's Index and by the percentage of polymorphic fragments (Table 3), revealed adequate variability rates within each population, agreeing with the presence of limiting and exclusive fragments, even in the presence of low frequency fragments. Population B (upstream) had the greatest variability. According to Lopera-
Barrero et al. (2010), populations with a great number of specimens or natural populations with high genetic variation allow variability among the specimens. Results of current assay showed that the natural stocks of $S$. brasiliensis have adequate intrapopulation genetic variation, especially in population B (upstream). 
Table 3. Number of specimens (N), Shannon's genetic diversity index (SI) and percentage of polymorphic fragments (PF) for populations of $S$. brasiliensis.

\begin{tabular}{cccc}
\hline Population & N & SI & PF \\
\hline A & 26 & 0.300 & 60.80 \\
B & 30 & 0.411 & 79.40 \\
\hline
\end{tabular}

Comparative analysis in grouping A x B with AMOVA revealed that most variations are within each population rather than between them. Distance and identity showed high genetic distance (Table 4). Results were corroborated by Fst (0.186) and
Nm (4.17) rates. According to Wright (1978), there was high genetic differentiation, with a low number of migrants $\left(\chi^{2}: 20.83\right)$. Genetic differentiation detected by the presence of exclusive fragments is evident, and revealed that the two populations have a different genetic structure.

Table 4. Analysis of molecular variance (AMOVA), variation source (VS), sum of squares (SS), coefficient of variation $(\mathrm{CV})$, percentage of variation $(\% \mathrm{~V})$, distance (D) and genetic identity (I) in populations of S. brasiliensis.

\begin{tabular}{ccccccc}
\hline Grouping & VS & SS & CV & \%V & D & I \\
\hline \multirow{3}{*}{ A x B } & B.P & 73.702 & 2.37441 & $18.61 *$ & 0.076 & 0.927 \\
& W.P & 539.983 & 10.38429 & 81.39 & & \\
\cline { 2 - 7 } & Total & 613.685 & 12.75870 & 100 & & \\
\hline
\end{tabular}

$* \mathrm{P}<0.05$. B.P. $=$ between populations. W.P. $=$ within populations.

Studies on S. brasiliensis populations captured in the transposition ladders of HPPs were undertaken to analyze the genetic variability of the species during the passage of fish upstream the dam. Lopes et al. (2007) reported a greater variability within each population in the HPPs Canoas I and Canoas II on the Paranapanema river, Brazil, than there was among populations (1.78\%). The same authors also reported low genetic differentiation $($ Fst $=0.018 ; \mathrm{p}<0.05)$ and low genetic distance (0.015) and concluded that the specimens of the two populations were genetically structured as a single population. Results differed from those in current assay: populations downstream and upstream the Cachoeira Branca indicated high genetic difference (Fst $=0.186 ; p<0.05)$ and showed that the specimens of each group were structurally two different populations. On the other hand, Gomes et al. (2013) studied S. brasiliensis captured on the transposition ladder in Canoas I and registered Fst (0.198 - 0.372) and $\mathrm{Nm}$ (1.68 - 4.35) rates revealing different structurally different populations. Current research showed that $\mathrm{Nm}$ rates also indicated low gene flow between populations A and B. Nevertheless, gene flow exists and mainly occurs upstream to downstream the waterfall, although the gene flow is impaired when the HPP was constructed.

Marteleto (2015) studied Astyanax bifasciatus population in the Jordão river (formed by the Pedras and Bananas rivers) and compared the variability of the species by microsatellite markers and sequencing in regions with populations upstream the Salto de Curucaca (the region close to the river source) and populations downstream Salto de Curucaca where four small hydroelectric power units were established. Fst rates revealed that populations downstream Salto de Curucaca (where populations of the dams are) were genetically less different 
than the populations upstream Salto de Curucaca. This fact revealed that the natural barrier had a major role in the genetic formation of populations within the different regions evaluated, due to the recent construction of the dams which did not cause great genetic difference between the populations. The above contrasts the region upstream Salto de Curucaca, or rather, there exists great differentiation when compared to the region downstream, mainly due to the formation of the Jordão river by two other rivers (Pedras and Bananas) with different populations of Astyanax bifasciatus. The same author underscores the existence of an unequal flow between the populations since the waterfall is a downstream/upstream barrier, featuring difficulty connection between the sub-populations. The Cachoeira Branca works similarly, as shown by Marteleto (2015), since the populations downstream the waterfall do not connect themselves to the population upstream, even though the flow of specimens is possible between the upstream and downstream regions, with an unequal flow between the groups. According to Kano et al. (2012), in extreme cases, isolation caused by waterfalls may trigger a parallel evolution among genetically distinct populations. Although there is still gene flow between the populations of the Cachoeira Branca, it may be presumed that the construction of the dam will produce future genetic differences.

According to Eletrobras-Eletrosul (2014), manual transposition activities during the 20132014 spawning period (piracema) occurred between September 2013 and May 2014, with 95 specimens of $S$. brasiliensis being transported to the São Domingos river (21 specimens), Araras river (56 specimens) and only 18 specimens to the river Verde. Since the dourado is a migratory species reproducing within the school of fish, it may be presumed that the number of specimens transposed to the Verde River was not sufficient to warrant reproduction success, even though the negative effects caused by dams cannot be minimized. Prior to the construction of the HPP São Domingos, the waterfall did not totally bar the migration of $S$. brasiliensis, in spite of low gene flow between populations A and B. The plant's transposition mechanism should allow the passage of fish in a controlled way since the upstream movement of a great number of specimens may empty the downstream stocks. However, no current mechanism is satisfactory in the downstream flow of the species (upstream to downstream). Such a flow would make possible a reduction of gene flow towards the mouth of the river and a higher equilibrium between the upstream and downstream regions of the dam. Further studies are required to evaluate the genetic variability upstream and downstream the dam and in the fish transposition ladder, for a better investigation of current gene flow in $S$. brasiliensis populations.

Dominant marker in current assay proved efficient in the study of genetic variability. Other studies with the same marker for $S$. brasiliensis (ALMEIDA et al., 2013; GOMES et al., 2011, 2013; LOPES et al., 2007) and in other fish species (JACOMETO et al., 2010; LOPERA-BARRERO et al., 2008b, 2010; LOPES et al., 2009; PAULA et al., 2006; POVH et al., 2008b) also gave positive results. In fact, dominant markers still have great possibilities of information for the initial review of genetic processes in natural populations or in fish stocks.

Genetic variability was high within each population and differences existed between downstream and upstream populations from the Cachoeira Branca with low gene flow among the specimens of the groups. The construction of the HPP São Domingos supposes changes of gene flow between the populations and a controlled fish transposition will be required to maintain the genetic variability between them.

\section{References}

Agostinho, A. A.; GOMES, L. C.; PELICICE, F. M. Ecologia e manejo de recursos pesqueiros em reservatórios do Brasil. Maringá: EDUEM, 2007. 501 p. 
ALMEIDA, F. S. de; LOPES, C. M.; ORSI, M. L.; SIROL, R. N.; SODRÉ, L. M. K. Genetic monitoring by RAPD markers for repopulation programs of Salminus brasiliensis (Pisces, Characiformes). Acta Scientiarum. Animal Sciences, Maringá, v. 35, n. 2, p. 119-126, 2013.

ANDRADE, E. de S. Aspectos da biologia reprodutiva de piapara (Leporinus obtusidens), capturados a jusante da Usina Hidrelétrica do Funil, Perdões/Minas Gerais. 2009. Dissertação (Mestrado em Ciências Veterinárias) Universidade Federal de Lavras, Lavras.

ARrAis, A. A.; COSTA, A. B. da; KÖHLER, A. Implantação de sistema de transposição para peixes junto a hidrelétricas: aspectos técnicos a serem considerados para as pequenas centrais hidrelétricas. Caderno de Pesquisa, São Paulo, v. 24, n. 2, p. 71-93, 2013.

BRASIL. Banco de informações de geração da ANEEL. Cidade: Editora, 2015. Disponível em: $<$ http://www.aneel. gov.br/aplicacoes/capacidadebrasil/capacidadebrasil. cfm>. Acesso em: 11 jul. 2015.

ELETROBRAS-ELETROSUL. $4^{\circ}$ Relatório semestral de andamento dos programas de planos ambientais. Usina Hidroelétrica São Domingos. Cidade: Florianópolis, 2014. Disponível em: <http://www.eletrosul.gov.br/ files/files/Doc.\%20socioambientais\%20UHSD/UHSD Relat_Sem_4_set_2014_Volume_I. pdf $>$. Acesso em: 9 jul. 2015.

EXCOFFIER, L.; LAVAL, G.; SCHNEIDER, S. Arlequin (version 3. 0): an integrated software package for population genetics data analysis. Evolutionary Bioinformatics Online, Auckland, v. 1, n. 1, p. 47-50, 2005.

EXCOFFIER, L.; SMOUSE, P. E.; QUATTRO, J. M. Analysis of molecular variance inferred from metric distances among DNA haplotypes: application to human mitochondrial DNA restriction data. Genetics, Bethesda, v. 131, n. 2, p. 479-491, 1992.

FLORA, M. A. D.; MASCHKE, F.; FERREIRA, C. C.; PEDRON, F. A. Biologia e cultivo do dourado (Salminus brasiliensis). Acta Veterinária Brasílica, Mossoró, v. 4, n. 1, p. 7-14, 2010.

FRACALOSSI, D. M.; ZANIBONI FILHO, E.; MEURER, S. No rastro das espécies nativas. Panorama da Aquicultura, Rio de Janeiro, v. 12, n. 6, p. 43-49, 2002.

GOMES, P. C.; LOPERA-BARRERO, N. M.; VARGAS, L.; STREIT JUNIOR, D. P.; POVH, J. A.; SIROL, R. N.; RIBEIRO, R. P. Genetic diversity of Salminus brasiliensis (Characiformes: Characidae) collected in the passage ladder of the Canoas I hydropower plant in the Paranapanema River, Brazil. Semina: Ciências Agrárias, Londrina, v. 34, n. 3, p. 1421-1432, 2013.
GOMES, P. C.; RIBEIRO, R. P.; SIROL, R. N.; LOPERABARRETO, N. M.; MOREIRA, H. L. M.; JAYME POHV, J. A.; MANGOLIN, C. A.; VARGAS, L.; JACOMETO, C. B.; STREIT JÚNIOR, D. P. Diversidade genética de dourado utilizado em programas de repovoamento no rio Paranapanema. Pesquisa Agropecuária Brasileira, Brasília, v. 46, n. 2, p. 167-176, 2011.

JACOMETO, C.B.;BARRERO,N.M.L.;RODRIGUEZRODRIGUES, M. D. P.; GOMES, P. C.; PAYH, J. A.; STREIT JÚNIOR, D. P.; VARGAS, L.; RESENDE, E. K.; RIBEIRO, R. P. Variabilidade genética em tambaquis (Teleostei: Characidae) de diferentes regiões do Brasil. Pesquisa Agropecuária Brasileira, Brasília, v. 45, n. 5, p. 481-487, 2010.

KANO, Y.; NISHIDA, S.; NAKAJIMA, J. Waterfalls drive parallel evolution in a freshwater goby. Ecology and evolution, Sheffield, v. 2, n. 8, p. 1805-1817, 2012.

LIMA, A. F. de; MAKRAKIS, M. C.; SILVA, P. S. da; DE AZEVEDO, A. V.; MAKRAKIS, S.; ASSUMPÇÃO, L. de; ANDRADE, F. F.; DIAS, J. H. P. Padrões de distribuição e ocorrência espaço-temporal de ovos e larvas de peixes nos rios Pardo e Anhanduí, bacia do alto rio Paraná, Brasil. Revista Brasileira de Biociências, Porto Alegre, v. 11, n. 1, p. 7-13, 2013.

LIMA, M. A. Desenvolvimento local e políticas públicas para comunidades atingidas por barragens: ocaso da Usina Hidrelétrica do Funil. 2015. Mestrado (Dissertação em Administração Pública) - Universidade Federal de Lavras, Lavras.

LOPERA-BARRERO, N. M.; RIBEIRO, R.P.; VARGAS, L.; POVH, J. A.; GOMES, P. C.; MANGOLIN, C. A.; BOSO, K. M. O.; GUALDA, T. Caracterização genética de estoques de Prochilodus lineatus (Valenciennes, 1836) (Characiformes: Prochilodontidae), utilizados em programas de repovoamento: importância para a conservação da ictiofauna e do ecossistema. Bioscience Journal, Uberlândia, v. 24, n. 4, p. 86-93, 2008b.

LOPERA-BARRERO, N. M.; POVH, J. A.; RIBEIRO, R. P.; GOMES, P. C.; JACOMETO, C. B.; LOPES, T. S. Comparación de protocolos de extracción de ADN con muestras de aleta y larva de peces: extracción modificada con cloruro de sodio. Ciencia e Investigación Agraria, Santiago, v. 35, n. 1, p. 76-86, 2008a.

LOPERA-BARRERO, N. M.; VARGAS, L.; SIROL, R. N.; RIBEIRO, R. P.; POVH, J. A.; MANGOLIN, C. A. Caracterização genética de Brycon orbignyanus utilizando o sistema seminatural. Arquivo Brasileiro de Medicina Veterinária e Zootecnia, Belo Horizonte, v. 62 , n. 1, p. 184-191, 2010. 
LOPES, C. M.;ALMEIDA, F. S.; ORSI, M. L.; CASTRO, S. G.; SIROL, R.; NARDEZ, R.; SODRÉ, L. M. K. Fish passage ladders from Canoas Complex - Paranapanema River: evaluation of genetic structure maintenance of Salminus brasiliensis (Teleostei: Characiformes). Neotropical Ichthyology, Maringá, v. 5, n. 2, p. 131-138, 2007.

LOPES, T. S.; STREIT JUNIOR, D. P.; RIBEIRO, R. P., POVH, J. A.; LOPERA-BARRERO, N. M.; VARGAS, L.; PINTO FILHO, C.; QUEIROZ, J. R. Diversidade genética de estoques de reprodutores de Colossoma macropomum. Arquivo Brasileiro de Medicina Veterinária e Zootecnia, Belo Horizonte, v. 61, n. 3, p. 728-735, 2009.

MARTELETO, F. M. Os efeitos da introdução de barreiras artificiais em rios sobre a genética populacional em peixes. 2015. Doutorado (Tese em Ciências Biológicas) Universidade Federal do Paraná, Curitiba.

MILLER, M. P. Tools for population genetic analyses (TFPGA): a Windows program for the analysis of allozyme and molecular population genetic data. Version 1. 3. Flagstaff: Northern Arizona University, 1997. 33 p.

PAUlA, F. M. Diversidade genética de Prochilodus lineatus (Pisces Characiformes) das escadas de transposição de peixes das usinas hidroelétricas do complexo Canoas - Rio Paranapanema. 2006. Mestrado (Dissertação em Genética e Biologia Molecular) Universidade Estadual de Londrina, Londrina.

POVH, J. A.; RIBEIRO, R. P.; SIROL, R. N.; STREIT JÚNIOR, D. P.; LOPERA-BARRERO, N. M.; VARGAS, L.; GOMES, P. C.; LOPES, T. S. Diversidade genética de pacu do rio Paranapanema e do estoque de um programa de repovoamento. Pesquisa Agropecuária Brasileira, Brasília, v. 43, n. 2, p. 201-206, 2008b.

POVH, J. A.; LOPERA-BARRERO, N. M.; RIBEIRO, R. P.; LUPCHINSKI JUNIOR, E.; GOMES, P. C.; LOPES, T. S. Monitoreo genético de programas de repoblamiento de peces mediante marcadores moleculares. Ciencia e Investigación Agraria, Santiago, v. 35, n. 1, p. 25-35, 2008a.
RAYMOND, M.; ROUSSET, F. An exact test for population differentiation. Evolution, New York, v. 49, n. 6, p. 1280-1283, 1995.

SAURA, M.; CABAlleRO, P.; CABALlERO, A.; MORÁN, P. Genetic variation in restored Atlantic salmon (Salmo salar L.) populations in the Ulla and Lérez rivers, Galicia, Spain. ICES Journal of Marine. Science, Galicia, v. 63, n. 7, p. 1290-1296, 2006.

SIROL, R. N.; BRITTO, S. G. Conservação e manejo da ictiofauna: repovoamento. In: NOGUEIRA, M. G.; HENRY, R.; JORCIN, A. (Ed.). Ecologia de reservatórios: impactos potenciais, ações de manejo e sistemas em cascata. São Carlos: Rima, 2006. p. 275-284.

SUZUKI, F. M. Estudo do comportamento de peixes no canal de fuga da usina hidrelétrica de Três Marias utilizando telemetria acústica. 2014. Doutorado (Tese em Ecologia Aplicada - Ecologia e Conservação de Recursos em Paisagens Fragmentadas e Agrossistemas) - Universidade Federal de Lavras, Lavras.

WEIR, B. S.; COCKERHAM, C. C. Estimating F statistics for the analysis of population structure. Evolution, New York, v. 38, n. 6, p. 1358-1370, 1984.

WILLIAMS, J. G. K.; RAFALSKI, J. A.; KUBELIK, A. R.; LIVAK, K. J.; TINGEY, S. V. DNA polymorphism amplified by arbitrary primers are useful as genetic markers. Nucleic Acids Research, Oxford v. 18, n. 22, p. 6531-6535, 1990.

WORKMAN, P. L.; NISWANDER, J. D. Population studies on southwestern Indian tribes. II. Local genetic differentiation in the Papago. American Journal of Human Genetic, Chicago, v. 22, n. 1, p. 24-49, 1970.

WRIGHT, S. Evolution and the genetics of populations. Chicago: University of Chicago, 1978. 580 p.

YEH, F. C.; BOYLE, T. Y. Z.; XIYAN, J. M. PopGene Version 1. 31: microsoft Window-based freeware for population genetic analysis. Alberta: University of Alberta and Center for International Forestry Research, 1999. $29 \mathrm{p}$. 
